\title{
Cintas, medidas y estadales de la Virgen (Colección del Museo Nacional de Antropología)
}

\author{
M. ${ }^{A}$ ANTONia HERradón Figueroa \\ Museo Nacional de Antropología. Madrid
}

\section{RESUMEN}

A través de la investigación de fuentes literarias, la autora estudia las cintas, las medidas y los estadales de la Virgen María, que constituyen un destacado y a la vez desconocido capítulo de la tradición religiosa en España. En el desarrollo del tema, el estudio de las fuentes escritas se contrasta con el análisis de piezas conservadas en el Museo Nacional de Antropología de Madrid.

\section{SUMMARY}

The author analyzes literary sources as well as exhibits of the Museo Nacional de Antropología in Madrid regarding the cintas, medidas and estadales of images of Mary, a little known but significant aspect of Spain's religious tradition.

Palabras clave: Virgen María. Medida. Prácticas religiosas. Santuarios. Embarazo. Parto.

Key words: Mary. Sash. Religious practices. Sanctuaries. Pregnancy. Childbirth.

\author{
Y el estadál roxo, \\ con lo que le cuelga, \\ que truxo el vecino, \\ quando fue à la feria (Góngora)
}

En esencia la religión católica se basa en un conjunto de principios abstractos e inmateriales, los cuales regulan todas las relaciones que el hombre establece con Dios, Jesucristo, María y los santos. El ser humano, sin embargo, necesita ver, oír, tocar y poseer, al menos una parte de lo que configura su dimensión espiritual y religiosa. En la necesidad de aprehender las abstracciones y de hacer visible el diálogo con seres superiores se encuentra el origen de ritos, prácticas, devociones, etc. esta-

RDTP, LVI, 2 (2001): 33-66 
blecidos, autorizados y/o tolerados por la Iglesia Católica a lo largo de dos mil años.

A su vez, el orden religioso así dispuesto se acerca todavía más al hombre, gracias a un formidable conjunto de elementos de carácter material. Estos objetos son los que, en mayor medida, han permitido establecer unos intercambios directos, sin intermediarios, y por tanto más fructíferos, entre los dos polos del binomio divinidad-ser humano. Debido al significado que encierran, su sentido fundamental no ha sufrido cambios significativos con el paso del tiempo. Tan sólo se advierten en ellos ligeras variaciones, a veces formales, a veces de interpretación, resultado de su permanente adaptación a nuevas situaciones y necesidades.

Algunos de los elementos que constituyen este universo objetual, tales como imágenes, pinturas o vidrieras han desempeñado en determinadas épocas una función claramente pedagógica. Otros, como medallas, estampas, gozos, aleluyas, rosarios, cruces, relicarios, exvotos, agnusdei, escapularios o velas han sido los más genuinos testigos de la práctica religiosa cotidiana de las distintas generaciones de fieles, de sus sentimientos y de sus devociones.

En mayor o menor grado, en estos objetos confluyen valores muy diversos: arte, religión, economía, política, etc. De ahí que, en la mayoría de las ocasiones, su estudio haya sido abordado por especialistas de todas las disciplinas, que ofrecen puntos de vista diferentes pero complementarios entre sí. Sin embargo, esta afirmación no puede hacerse extensiva a ciertos objetos devocionales que, sin valor económico y sin significado artístico, han sido olvidados por la investigación.

En este punto se encuentran, por ejemplo, medidas y estadales, cuya historia se extiende desde la Edad Media hasta nuestros días.

\section{CINTAS, MEDIDAS, ESTADALES}

Salvo ciertos matices que se verán más adelante, se trata de términos sinónimos.

El más antiguo parece ser estadal, definido en el Diccionario Medieval Español como "medida de la estatura". Covarrubias en 1611 insiste en la misma idea: "También es medida que se toma en el espacio que ay de las puntas de los dedos de una mano a otra, que es la mesma que ay de pies a cabeça, de manera que la estatura de un hombre se puede tomar de pies a cabeça, o de mano a mano, estendiéndolas, y de aquí se llamó estadal de cera la hilada que descogiéndola tendrá comúnmente el largo de la estatura del hombre [...]. 
Un siglo más tarde, el Diccionario de Autoridades (1726-1737) precisa un poco más, al definir estadal de cera: "Es la hilada, que descogiéndola suele tener de largo la estatura de un hombre: y aunque en lo antiguo se le dio este nombre à la hilada de cera, o torcido de cera ó cerilla, porque comunmente no excedía de la medida del estadál, ahóra no se lleva esta cuenta, si no se pagan las onzas ó libras que pesan las hiladas, y todo el conjunto de esta se llama estadál. El mayor interés de esta definición aparece al final cuando dice "Es mui usual en Andalucía". Además, aquí figura ya estadal como "especie de dixe, que parece se usó antes, y se ponía al hombron.

Para terminar, María Moliner dice que estadal, en su segunda acepción, es una "cinta bendita con la medida de la efigie de algún santo, que se lleva por devoción, por ejemplo al cuello".

Según el Diccionario de Autoridades, "Medida se llama asimismo la cinta, que se corta igual a la altura de la imagen o estatura de algún Santo, en que se suele estampar su figura, y las letras de su nombre con plata ú oro. Usase por devoción".

Y María Moliner, prescindiendo de los detalles decorativos derivados del empleo de metales preciosos, la define como "cinta cortada a la medida de una imagen en que se estampa el nombre de ésta y a veces una reproducción de ella, que se tiene o lleva encima como objeto de devoción".

Así pues, tanto la medida como el estadal son objetos de devoción en forma de cinta, cuya medida coincide con la de alguna imagen religiosa. Las diferencias entre ambos parecen derivarse de la forma de uso: mientras que el estadal se lleva al hombro o al cuello, la medida se tiene en casa o se lleva en el bolsillo o sujeta a la ropa. Por otra parte, el estadal parece especialmente característico de Andalucía. Más adelante insistiré en estos aspectos.

La práctica de medir iconos sagrados tiene su origen en los Santos Lugares, desde donde los peregrinos trajeron hasta Europa Occidental las medidas del sepulcro de Cristo y de la columna de la flagelación. Del mismo modo, medidas y estadales se han adquirido siempre, y se adquieren aún, en los respectivos santuarios: visitar éstos también es el resultado de una peregrinación o romería, es decir, de un camino recorrido cuya meta es la divinidad. Su elevado poder evocador y, por tanto, su marcado carácter devocional, está relacionado con dos circunstancias: por un lado, la cinta reproduce la dimensión de la imagen venerada; por otro, esa cinta asume por contacto las virtudes de dicha imagen. Al comprar la medida, el devoto adquiere un símbolo divino, real y tangible, en el que están presentes, además, determinados poderes sobrenaturales. 
En general, puede afirmarse que no resulta sencillo encontrar referencias a cintas, medidas y estadales. Se trata en la mayoría de los casos de noticias dispersas, que aparecen en cánones de concilios, documentos de archivo y, a partir de los siglos XVI y XVII, en las historias relativas a los diferentes santuarios y advocaciones. Compilaciones como el Jardín de María plantado en el Principado de Cataluña, de Fray Narciso Camós (1657), también citan en ocasiones las medidas, pero sólo como uno más de los numerosos objetos de recuerdo que adquirían los peregrinos, mediante los cuales la Virgen obraba el milagro.

Desde otra óptica, hay que mencionar los comentarios al respecto de los extranjeros que viajaron por España durante el siglo xIx, más críticos que los auspiciados de manera directa por las autoridades eclesiásticas.

Otra fuente muy interesante de información la constituyen las encuestas, el sistema de obtención de datos por excelencia utilizado por los folkloristas a partir de las últimas décadas del siglo XIX. En esta línea se encuentra la Encuesta del Ateneo de Madrid sobre costumbres de nacimiento, matrimonio y muerte, de la que ahora se conmemora el primer centenario. A pesar de sus conocidas limitaciones, derivadas, por una parte, de la metodología utilizada en la obtención de datos y, por otra, del irregular volumen de información recogida en relación con todo el territorio nacional, constituye un valioso testimonio de las costumbres, entonces calificadas como populares, desarrolladas en torno al ciclo vital (Limón Delgado y Castellote Herrero 1991) ${ }^{1}$.

Las medidas figuran en la Encuesta en los capítulos relativos al inicio del ciclo vital: concepción, gestación y, sobre todo, alumbramiento. Sin embargo, las referencias son en conjunto muy escasas. Dos respuestas, procedentes de Barcelona y Manresa, se refieren al concurso de las cintas en la concepción; cinco respuestas, correspondientes a Salamanca, Barbadillo de Herreros (Burgos), Logroño, Ricla (Zaragoza) y Aliste de Alba (Zamora), las relacionan con la gestación; y ocho, las de Burgos, Madrid, Burriana (Castellón), Menorca, Noya (La Coruña), Santander, Jaca (Huesca) y Barcelona, con los partos. Pero los santos y las advocaciones marianas cuyas cintas se mencionan en estas respuestas ofrecen muy distintos niveles de especialización en caso de partos y embarazos. Por otra parte, los santuarios en los que se veneran también poseen un radio de acción muy diferente, determinado por una tradición que se sustenta de manera directa en el poder de convocatoria de cada imagen.

\footnotetext{
${ }^{1}$ Los datos expuestos a continuación proceden de los capítulos dedicados a la concepción, a la gestación y al parto.
} 
En primer lugar hay que mencionar las advocaciones de carácter local, intercesoras naturales e inmediatas ante toda situación conflictiva, vivida por los fieles del entorno más próximo. Es el caso de la Virgen del Toro, patrona de Menorca. O de santa Severa, venerada en la barcelonesa parroquia de san Pedro. Otras veces las citas conducen a imágenes con influencia sobre una determinada comarca o región. En este grupo se encuentran, por ejemplo, santa Orosia, patrona de la diócesis de Jaca (Huesca), santa Casilda, a cuyo santuario de Briviesca (Burgos) acuden fieles de todas las provincias colindantes y santo Domingo de Silos. Y vírgenes como la de Montserrat o la de Nuria, ambas veneradas en toda Cataluña. Aquí se advierte, por un lado, una efectividad mayor en sus intervenciones ante las desgracias y, por otro, una especialización contrastada en las situaciones comentadas. Por último, la Encuesta menciona cintas pertenecientes a santuarios de influencia nacional, ya sea debido al patronazgo universal ejercido por la advocación, caso de la Virgen del Pilar, bien sea por su tradicional efectividad demostrada en partos conflictivos, caso de la Virgen de la Cinta de Tortosa.

Resumiendo, la información recogida por el Ateneo hace cien años se hace eco de las medidas de algunos santos y de un puñado de advocaciones marianas. La sucinta relación resultante viene a confirmar, una vez más, que las respuestas describen sólo una mínima parte de la extensión del fenómeno. Porque en realidad, del amplio conjunto de documentación consultada parece deducirse que, al menos desde el siglo XVI, todo santuario con un mínimo prestigio ha contado no solo con medallas y estampas propias, sino también con la correspondiente medida. No obstante, parece que de forma paralela a la propagación de las cintas se detecta una cierta cautela hacia las mismas por parte de la jerarquía eclesiástica. Así, al mismo momento se refiere, precisamente, la prohibición del uso de medidas establecida en 1565 en el concilio de Valencia: "Que nadie mida las imágenes de los santos con hilos o cualquiera otra cosa, para llevar las medidas a los enfermos, ni se den a éstos las hostias en que suelen escribirse algunas cosas; pues todo esto respira superstición" (Christian 1991: 323). Claro que al margen de las prohibiciones las medidas se continuaron usando en todo el país.

\section{USO DE LAS MEDIDAS}

Si bien las distintas fuentes mencionan la intervención milagrosa de las medidas o cintas en hechos y acontecimientos negativos de toda índole, como epidemias, sequías, plagas, guerras, redenciones de cautivos, 
curaciones, accidentes, etc., los mismos documentos informan - la Encuesta es tan sólo un ejemplo de ello- de su estrecha y especial vinculación con las distintas circunstancias que rodean el inicio del ciclo vital.

Entre las relaciones que pueden establecerse entre el objeto y su significado, la más obvia tiene su origen en la definición de cinta. Dice Covarrubias que "Estar en cinta, es estar preñada, porque tiene ceñida la criaturan. Una conexión de mayor complejidad supone poner en contacto las medidas con las personas sagradas a las que representan.

Como he señalado más arriba, las medidas más antiguas hacen referencia a ciertos objetos de especial valor simbólico para el cristianismo, como la columna de la flagelación o el sepulcro de Jesús. Así, en una pieza del Museo Nacional de Antropología figura la leyenda Longitvdo Sanctissimi Sepulchri Domini Nostri Iesuchristi (n. ${ }^{\circ}$ inv. 9360). Aún siendo este tipo de medidas el menos frecuente y, por tanto, el menos conocido, en ellas también se advierte una relación con el parto (Llompart 1984: 246) ${ }^{2}$.

Pero fundamentalmente las cintas aparecen vinculadas con determinados santos y, sobre todo, con la Virgen María. La hagiografía de casi todos los santos que han sido medidos incluye uno o varios pasajes relacionados con el embarazo o con el alumbramiento. Es el caso del leridano san Ramón Nonato, que fue sacado vivo del vientre de su madre muerta. Este hecho lo convirtió en el abogado por excelencia de toda parturienta sin distinción de clases sociales. Así, incluso Isabel II, con motivo de su cuarto parto, aceptó gustosa el ofrecimiento del traslado desde Cervera "de las reliquias del citado santo, junto con las medidas y velas del buen alumbramiento para lograrle feliz por la intercesión de tan glorioso santom. Según los testimonios recogidos por Cortés, estas medidas medían el perímetro del cráneo de san Ramón (Cortés Echanove 1958: 311).

Parecido es el caso de santa Casilda de Toledo (Siglo XI), enferma de flujos de sangre, lo que la relaciona con la fecundidad. Sus cintas se adquieren en su santuario de Briviesca (Burgos) y tienen la medida exacta de la imagen de la santa. En Madrid, la parroquia de Santa Casilda también expende estas medidas, que todavía hoy son enviadas directamente por el capellán de la ermita burgalesa. O de santo Domingo de Silos, venerado desde la Edad Media como protector de partos: en el siglo XIII la madre de santo Domingo de Guzmán había suplicado su intercesión

${ }^{2}$ A propósito del lienzo con la imagen de Jesús expuesto en la capilla de la catedral de Valencia llamada "capilla de la santa Longitut", el autor afirma que la medida de la imagen se consideraba entre el pueblo eficaz remedio para no abortar y facilitar el parto. 
para tener un buen alumbramiento. Por este motivo, desde 1609, cuando fue solicitado por vez primera por la esposa de Felipe III, Margarita de Austria, el báculo de santo Domingo de Silos siempre estuvo presente en los partos de las reinas españolas. En 1882 la reliquia fue incluso objeto de un artículo - con dibujo incluido- en La Ilustración Española y Americana (Cortés Echanove 1958: XXVI). Las cintas tocadas al báculo o a la propia imagen del santo sustituían a aquél en los partos no reales, es decir, en todas las demás ocasiones.

Pero aún siendo elevado el número de santos invocados en los partos -además de los anteriores hay que mencionar a san Valentín, san Pedro Claver, san Félix de Cantalicio, santa Felicitas, santa Margarita, etc.-, la casi totalidad de las medidas que conozco y cuya noticia se conserva tienen como protagonista a la Virgen María. A partir de la Edad Media se produjo en España una lenta pero imparable transformación en las devociones que, desde los santos, acabaron centrándose en la figura de María. Las reflexiones de W. Christian (1976: 65-66) informan de las circunstancias bajo las que se produjo este cambio y sus consecuencias:

\begin{abstract}
Los santuarios que predominaban en España antes del siglo XII, que eran los que tenían los cuerpos de los santos o las más importantes reliquias, estaban singularmente localizados en las grandes poblaciones. La aceptación de las imágenes en la Iglesia de la Europa de Oeste libertó la devoción popular cristiana de estas localidades urbanas y de cabezas de diócesis y permitió la sacralización de la campiña. A partir del siglo XII, las estatuas de María fueron incorporadas como imágenes de devoción en lugares de la campiña que tenían una significación simbólica para la comunidad agrícola o pastoril, como, por ejemplo, las fuentes, las cimas de las montañas, los altos de caminos y las grutas y las cuevas. Se sabe que la cristianización del campo fue un proceso lento. El culto de las imágenes proveyó una manera de extender esta religión a los lugares de la campiña que eran considerados a través de creencias precristianas como puntos críticos de contacto con las fuerzas de la naturaleza más allá del control del individuo o de la comunidad rural. María, como imagen de madre con su niño, fue una figura particularmente apropiada para estas localidades, era la imagen cristiana que mejor pudo simbolizar la fertilidad y la protección maternal.
\end{abstract}

La figura de la Virgen se constituye, pues, en la heredera natural del culto recibido con anterioridad por los santos. María es, además de madre, símbolo de fertilidad y protección, la mejor intercesora entre Dios y los hombres: como tal, manifiesta su poder taumatúrgico en las situaciones difíciles que atraviesan éstos últimos. Y no cabe duda de que los embarazos y partos lo han sido hasta fechas muy recientes.

Sin embargo, frente a la tradicional abundancia de reliquias de santos en todo el occidente cristiano, la inexistencia de reliquias marianas hizo necesario disponer de elementos tangibles, más allá de la propia imagen 
de piedra o madera, que canalizaran la devoción. En algunos santuarios marianos, la falta de reliquias auténticas se paliaba mediante determinados restos inorgánicos. En la ermita de la Virgen del Tallat (Vallbona de les Monges, Tarragona), los devotos se llevaban fragmentos de roca de la puerta izquierda del altar, una piedra con propiedades supuestamente milagrosas. Junto al santuario de la Virgen del Milagro (Riner, Lérida) existe un dolmen denominado "piedra de la Virgen" que curaba por contacto el dolor de cabeza. Y en el de la Virgen de Butsénit (Butsénit, Lérida), una piedra o pedreta, era el objeto que, impuesto sobre el órgano enfermo, obraba las curaciones.

También los elementos de naturaleza textil relacionados con las imágenes marianas han sido tradicionalmente venerados como reliquias. El ejemplo más extremo a este respecto lo constituyen los mantos de la Virgen del Pilar, hasta fechas muy recientes pedidos para los enfermos de todo tipo por sus supuestas propiedades curativas y también para las parturientas. La misma consideración han tenido los mantos de otras muchas vírgenes. En relación con la Virgen de Nuria (Caralps, Gerona), cuenta la tradición que un sacerdote, queriendo celebrar la santa misa y faltándole casulla, inesperadamente encontró una encima del altar de la Virgen. Esta prenda desapareció paulatinamente porque los devotos se llevaban retales de ella a manera de reliquias (Guía para visitar los santuarios marianos de Cataluña 1988: 310). Los ejemplos citados no constituyen, ni mucho menos, casos aislados en la tradición religiosa española. Hay que decir, además, que se conocen medidas de los cinco santuarios mencionados. Es evidente que el devoto siempre ha querido poseer, aún de manera temporal, algún elemento íntimamente relacionado con la Virgen, es decir, alguna reliquia.

En este contexto, es posible pensar que las medidas fueran consideradas, en origen, como un vestigio material de la figura de María. Como tal, las cintas se acabaron convirtiendo, pues, en un nuevo modelo de reliquia y, por tanto, en un nuevo objeto de devoción. Desde el siglo XVII cintas, medidas y estadales se denominan en la bibliografía "reliquias", consideradas dignas de veneración por haber estado en contacto con la imagen sagrada.

A este respecto creo interesante mencionar, por su singularidad, la información recogida por Amades acerca de la Medida del zapato de la Virgen Maria, que se venera como una reliquia en el santuario de la Virgen de Bellpuig, impreso que venden los administradores del santuario. Este es el pie de foto que acompaña la silueta de un pie, realizada con orla tipográfica, en cuyo interior figura un texto en catalán. Dice así: "Mida justa del peu de la Santísima verge Mare de Déu, treta de la seva veritable 
Sabata, que es venera amb gran devoció en un convent de Loreto, al regne d'Itàlia, ciutat en què es conserva la seva santísima Casa portada miraculosament per mà dels àngels de Jerusalem. El Sant Pare Joan XXII va concedir 300 anys d'indulgències a qui besi tres vegades aquesta mida $i$ digui tres avemaries, indulgènticies que foren confirmades pel $S$. Pare Climent VIII l'any de nostra redempció de 1603. Com que aquestes indulgeències no tenen prescipció de nombre, poden guanyar-les totes les vegades que vulguin al dia els devots de la Santísima Verge María i es poden també aplicar per les ànimes del purgatori. Per a major gloria de la Reina del cel i de la terra és permès treure d'aquesta mida d'altres de semblants, les quals gaudiran de les mateixes indulgències.-Aquesta festivitat es celebra a Italia el 10 de desembrem. El impreso corresponde a finales del siglo XviI o principios del XviII (Amades 1950: 4, 843) ${ }^{3}$.

Así pues, si las medidas fueron consideradas "reliquias", podríamos estar ante el objeto que marca el estadio intermedio entre las reliquias de santos propiamente dichas y las medallas o estampas, objetos que igualmente reproducen la imagen venerada y que también suelen, o solían más bien, estar tocados a la imagen, pero que, sin embargo, nunca se han denominado "reliquias".

Pero la evolución de las medidas no parece terminar en este punto. Porque además de las cintas que reproducen la altura de la imagen, el perímetro de su cabeza, la longitud del brazo o la cintura, algunos santuarios disponen de otras similares - aunque ahora sus dimensiones no se ajusten a ninguna de las de la imagen-, que a veces llegan incluso a sustituir a las primeras. En ellas figura siempre el nombre de la virgen, pero nunca la leyenda "medida de..... Probablemente se trata de objetos de recuerdo que, aún perdiendo el sentido primitivo de las medidas, han mantenido sin embargo la forma de cinta, reconocida, asumida y venerada por los devotos.

\section{ASPECTO FORMAL}

Con toda seguridad, las medidas más primitivas no fueron cintas tal y como hoy las entendemos, sino simples hilos o cordones, más o menos gruesos. Además de la referencia del concilio valenciano ya comentada, otras informaciones, procedentes de distintos lugares de nuestra geogra-

${ }^{3}$ La Virgen de Bellpuig (Bellpuig, Lérida) fue hallada junto a uno de los zapatos de la Virgen, que era de una especie de cordobán rojo y que se guardaba en un relicario de plata. La romería se celebraba el 15 de agosto. 
fía, conducen a la misma afirmación. Así, sabemos que el ermitaño del santuario de san Cosme y san Damián de la Sierra de Guara (Huesca) ofrecía a cambio de las limosnas unos cordones con la medida de las imágenes; los montañeses se ataban el cordón a la muñeca o al ojal de la chaqueta (Satué Oliván 1991: 198). El uso de los cordones no pertenece en exclusiva al pasado remoto, como indica el que aún hoy se bendigan los denominados "cordones de la Virgen" en la romería de la Virgen de Gracia de Carmona. En la comarca salmantina de La Ribera se acude a esta necesidad poniéndose la mujer que desea tener hijos una medida del Santo Cristo. Consiste ésta en una cinta de hiladillo ${ }^{4}$ blanco lo suficientemente larga para poder atarla a la cintura, donde se coloca después de haberla tocado a la sagrada imagen. Este es un remedio que también se aplica para la curación de aquellos males que la ciencia no puede combatir (Maldonado Ocampo 1952: 32, 126). Es lógico suponer que las medidas de esta naturaleza se hayan perdido.

Las más antiguas medidas de la Virgen conservadas forman una ancha banda, a modo de estola, de tejido de malla realizado con hilo de seda de distintos colores matizados. Como decoración llevan en sus extremos placas aplicadas de hueso o marfil con la imagen pintada de María. Pero casi todas las medidas que conozco son cintas de ancho variable, que oscila entre 1.5 y $6 \mathrm{~cm}$., realizadas con seda, algodón o poliéster. Si en los siglos pasados, la materia de la cinta estaba en relación con el poder adquisitivo del devoto y con su categoría social, en la actualidad, y desde hace medio siglo, las medidas se confeccionan exclusivamente con poliéster. En todos los casos se utilizan cintas de colores diversos: azul, verde, rojo, salmón, amarillo, blanco, rosa, morado, etc... Así, una misma imagen posee un cierto repertorio de medidas: por ejemplo, la Virgen del Pilar disponía, en octubre de 2000, de medidas de color azul, rojo, verde y rosa, más otra con los colores de la bandera española.

Las cintas están decoradas con distintos motivos estampados: claro que la plata y el oro de las medidas del siglo xviII se fueron sustituyendo a lo largo del siglo xIx por tintas de color negro o azul. En todas sin excepción figura una leyenda alusiva a la advocación, leyenda que puede incluir, además, una referencia precisa a la imagen o parte de la imagen representada: Medida de la cintura de..., Medida de la cabeza de..., Medida del brazo de..., Medida tocada a Nuestra Señora de..., Medida de la milagrosa imagen de..., etc. En las medidas de Cataluña las leyendas están por lo general en catalán: Mida del cap de...; Mida de la Mare de Deu

${ }^{4}$ Según el DRAE, el hiladillo es el hilo que sale de la maraña de la seda, el cual se hila en la rueca como el lino. También es una cinta estrecha de lino o seda. 
de..., etc.; los santuarios visitados por devotos de regiones colindantes disponen, no obstante, de medidas rotuladas tanto en castellano como en catalán.

La longitud de la leyenda suele estar delimitada por una pequeña marca en cada uno de sus extremos (estrellas, rosetas, cruces, geometrías varias, etc.). Estos motivos en apariencia sólo decorativos tienen sin embargo gran interés ya que en muchos casos la medida de la imagen no guarda relación con la longitud total de la cinta, sino con la distancia que separa ambas marcas. En este sentido hay que recordar que, debido a los cambios sufridos por el aspecto externo de las imágenes a lo largo de los siglos - cambios que a veces implican incluso la sustitución de la imagen antigua por una nueva- es bastante complicado establecer la dimensión exacta de la escultura. De ahí que, según la fuente consultada, las medidas de una misma imagen puedan variar entre sí varios centímetros. Por último, en las medidas también puede aparecer, igualmente estampada, la efigie de la imagen en cuestión o los motivos iconográficos que la representan.

En contra de lo que ha sucedido y sucede con medallas y estampas, las medidas siempre se han vendido en los propios santuarios, bajo la supervisión directa de los ermitaños o capellanes, y, en su caso, de los administradores de las correspondientes cofradías. Sin embargo, en ciertas ocasiones era el propio devoto - según Amades son las mujeres las que realizan esta práctica- quien preparaba su particular medida:

\footnotetext{
Hom porta a la imatge un bocí de cinta de seda, o de cotó, segons las possibilitats de la devota. La veta ha de tenir la mida fixada i les mateixes extensió i llargada que la mida. Hi ha casos en què la devota deixa la veta al santuari i se n'emporta una altra de les que hi han deixat altres fidels que l'han precedida en la pràctica, i fa una almoina amb destinació al culte. D'altres vegades, hom fa tocar la veta amb la imatge, per tal que cobri gràcia i virtut remeieres per efecte del contacte (Amades 1950: 5, 536).
}

Hay que pensar que las medidas así confeccionadas carecían de leyendas y de cualquier otro motivo decorativo y que, por tanto, su identificación fuera de contexto es imposible ${ }^{5}$.

\footnotetext{
${ }^{5}$ Aún hoy es posible encontrar este tipo de cintas: es el caso de la que se bendice y vende en la romería de san Blas de Aldeanueva del Camino, Cáceres. El ejemplar que conozco es de 1990: se trata de una cinta de raso azul sin ninguna particularidad destacable que permita identificarla como objeto de devoción. En referencia a la especialidad médica del santo, se ata a la garganta; algunos la conservan atada a esa parte del cuerpo durante todo el año. Con el mismo fin, desde hace algunos años también se venden cordones.
} 


\section{La COlECCiÓN DEL MuSEO NACIONAL DE ANTROPOlOGía}

El Museo Nacional de Antropología cuenta entre sus fondos con una colección de más de un centenar de medidas, pertenecientes a más de treinta santuarios de España y América. Salvo algunas excepciones, todas corresponden a advocaciones marianas. Esta característica se explica, en primer lugar, por la estrecha relación ya comentada entre las cintas y la Virgen María. En segundo lugar, porque la mayoría de ellas procede de la colección del sacerdote catalán Jordi Fort (Ripoll, Gerona, 1922), que reunió a lo largo de medio siglo de metódica y apasionada actividad un voluminoso conjunto de objetos, documentos y libros relacionados con la figura de María. El denominado por el propio Mosén Fort "Archivo Mariano" fue adquirido por el Estado en 1994.

La colección es en realidad el fruto del trabajo de dos hombres, porque Fort fue el continuador de la obra de Bartolomé Relimpio, que comenzó a recopilar materiales a comienzos del siglo xx. Ambos coleccionistas utilizaron el cuestionario como método, tanto para reunir información como para ponerse en contacto con las distintas autoridades religiosas locales, que fueron además las encargadas de remitir, entre otros, medallas, estampas, gozos, novenas, grabados, postales y medidas.

Quizá debido al origen de Jordi Fort y a la vinculación personal de Relimpio con Cataluña, la mayoría de las medidas procede del entorno más próximo, es decir, de las diócesis catalanas. El segundo grupo, destacable por el número de piezas que lo componen, procede de Andalucía, en particular de la diócesis de Jaén. El resto de las medidas son de santuarios puntuales diseminados por todo el país. No se trata, por tanto, de una colección que pueda considerarse completa. Por este motivo, las conclusiones aquí obtenidas no pueden tener un carácter definitivo.

\section{Medida de la Virgen de la Cinta (Tortosa, Tarragona). El objeto entregado}

La medida correspondiente a esta advocación es quizá la más singular de todas las españolas, ya que su historia se fundamenta en que fue entregada en persona por la Virgen. Además, gracias a esta circunstancia, en torno a ella se ha generado un volumen importante de literatura, tanto apologética como crítica.

La Virgen de la Cinta se venera en España desde finales del siglo XII. Según la leyenda religiosa, esta advocación tiene su origen en el año 1179, cuando la Virgen hizo entrega de su cinturón a un sacerdote de la cate- 
dral de Tortosa. Por otra parte, Joan Amades recoge otro relato tradicional, que relaciona este hecho con la defensa de Tortosa. Tras la reconquista de la ciudad, el conde Ramón Berenguer se dirigió a Lérida con su ejército, en el que había muchos hombres tortosinos. Aprovechando que las mujeres se quedaron solas en la ciudad, los sarracenos atacaron de nuevo. Las tortosinas defendieron la plaza ante el enemigo y, como premio a su valor, María les entregó su cinturón (Amades 1950: 4, 606). El objeto entregado es conocido con el nombre de santa Cinta o sagrado Cíngulo de la Virgen María.

En realidad se trata de uno más de los relatos que subrayan la especial relación que la Virgen María ha mantenido con los hombres desde los primeros tiempos del cristianismo y que, entre otras formas, se materializa en la entrega de determinadas prendas u objetos. La historia de la Iglesia de Occidente es pródiga en este tipo de narraciones milagrosas: en 665 la Virgen impone la casulla a san Ildefonso; en los inicios del siglo XIII, santo Domingo de Guzmán recibe el rosario; en 1251 san Simón Stock, el escapulario carmelita; a comienzos del siglo XVII santa Úrsula Benincasa recibe el escapulario azul, insignia de la Inmaculada Concepción; en 1830 María muestra a Catalina Labouré la medalla milagrosa. Todos ellos han sido profundamente venerados durante siglos, canalizando la devoción de los fieles.

Aunque algunos autores no están de acuerdo, creo que el relato apócrifo que narra la entrega del cinturón de la Virgen a Tomás, el apóstol incrédulo, puede considerarse, en su intención última, relacionado con los hechos localizados en Tortosa. Tomás creyó en la asunción de María merced al objeto entregado, que se convierte en objeto de fe. Así, la cinta de Tortosa se convierte en prueba material de la predilección de María por la ciudad y, al mismo tiempo, en instrumento de protección (Reau 1983: 3, 1267) ${ }^{6}$.

En la definitiva configuración de la devoción a la cinta parece ocupar un lugar especialmente destacado el tortosino Francisco Martorel y de Luna, autor de una completísima historia que vio la luz en 1627. Este texto supone un extraordinario compendio de las prácticas religiosas desarro-

\footnotetext{
${ }^{6}$ A pesar de lo dudoso del relato, el culto a santo Tomás echó raíces en Occidente, sobre todo en Toscana, precisamente gracias a la Sacra Cintola, entregada por la Virgen al apóstol. Según narra otra leyenda, en el siglo XII un joven de Prato viajó a Jerusalén y allí se casó con una joven que aportó como dote el cinturón sagrado. Con posterioridad, este tesoro fue legado a la colegiata de la ciudad italiana, donde se venera desde entonces. En el siglo XII aparecen, pues, en Europa, dos cinturones de la Virgen. En el caso italiano, el objeto fue supuestamente transmitido de generación en generación.
} 
lladas en torno a tan venerado objeto. Diez años antes se había fundado la Cofradía de Nuestra Señora de la Cinta, de manera que la fecha mencionada coincide con un período de organización de los rituales asociados a la advocación y a su reliquia 7 .

El Capítulo 16 del Libro segundo está dedicado por completo a las intervenciones milagrosas de la cinta en los partos difíciles. Se trata de veinte casos, que el autor recoge mediante el testimonio de uno o varios testigos de los hechos. Por ello, los relatos se fechan entre finales del siglo XVI y los primeros decenios del XVII: 1588, 1590, 1605, 1612, 1615, 1616, 1617, 1618 y 1626. Según se desprende de su lectura, la cinta obraba milagros en todo tipo de partos complicados, por supuesto sin tener en cuenta la clase social de la parturienta. Así, figuran como favorecidas por la Virgen las mujeres de un zapatero, de un platero, de un calcetero, de un mesonero, de un hortelano, de un pescador, de un escribano, de un médico, etc., pero también la de "un caballero de esta ciudad».

Todos los testigos se identifican mediante el nombre, el oficio y la edad. Entre ellos predominan los pertenecientes a la jerarquía eclesiástica, tales como presbíteros, beneficiados, racioneros, subdiáconos y otros sacerdotes vinculados a la catedral:

El venerable mossen Mateo Bono, presbítero, y Beneficiado en la dicha Seo, de edad de cincuenta y siete años, testigo presentado, y ofrecido sobre dicho octavo artículo, dixo demas de lo general (y atestiguó lo mismo sobre dicho artículo Sebastiá Parrot, marido, de edad de 33 años) que auia ya muchos años que el testigo, rogado lleuó la santa Cinta a casa de Sebastián parrot, Zapatero, cuya muger Cadia Cida estaua a la muerte por dificultad de parir, auiendo venyte y quatro horas que la criatura sacaua todo el braço entero, con grande peligro de la vida, y que en el momento en que el testigo puso la arquilla en que lleuaua dicha Reliquia sobre dicha muger, y rogando ella y el testigo, y los demas circunstantes a Dios y a su madre, hiciesen milagro en librar dicha muger de aquel peligro, porque entendían que era imposible el librarse de otra manera, según las circunstancias. El braço de la criatura se boluio dentro la matriz, y encontimente, con el modo natural, y ordinario pario vn niño viuo, y sano, con grande alegría de todos los presentes, los quales lo atribuyeron a milagro, hecho por Dios, mediante la deuocion de la dicha Reliquia (Martorel 1627: 498).

${ }^{7}$ Francisco MARTOREL Y DE LUNA, Historia de la antigua Hibera, con la milagrosa descensión de la Madre de Dios a su santo Templo, y la dadiua preciosa de la santa Cinta, dada por su sagrada mano. Descripción del Monte de Cardo, morada de los Religiosos Carmelitas Descalços, con variedad de Historia; y vna breue descripción de Cataluña, y su fidelidad (Impreso en Tortosa, en la imprenta de Jerónimo Gil, 1627). Está dividido en dos libros, el segundo con portada propia y paginación continuada a partir de la página 333: Libro segundo, Historia de la Santa Cinta, con que la Soberana Reyna de los Angeles bonró a la Catedral y Ciudad de Tortosa, con sus milagros, y fundación de su numerosa Cofradia. 
En otras ocasiones son las parturientas, e incluso las mismas parteras o comadres las que ratifican la veracidad de los milagros.

Un acta capitular fechada en 1620 señala que una pequeña parte de la cinta estaba separada de la otra mayor desde "tiempo inmemorial». Así la conoció Martorel, que describe no sólo la disposición de cada una de las partes, sino también el ceremonial seguido para la salida de la catedral del fragmento más pequeño, el que se llevaba a los enfermos y, sobre todo, a las parturientas:

[...] la vna está en vn Reliquiario grande dorado, bien labrado, ofrenda de su Ilustrísima señoria, la qual hizo quado salio Diputado de Cataluña, con la disposición que arriba diximos, entre vnos cristales. Este reliquiario está a parte, en vn armario grande de Reliqnias, en la Resacristia de la Seo, muy bien guardado, cerrado con tres llaues doradas, que se guardan en el Archiuo del Cabildo, y no salen de alli para abrir el Armario, sino es precediendo determinación capitular, y solo sale en publico, y se enseña al Pueblo ed dia de la fiesta principal, y el dia de la Anunciación, que es tambien fiesta de la Cofradía: La otra parte de la Cinta está en la arquilla dorada, que se lleua en las procesiones de la Cofradía cada segundo Domingo de mes, cerrada con llaue y bien guardada. Esta no se enseña en publico. Esta parte que está en la arquilla cerrada, es la que se lleua a las mugeres que van de parto, y están en peligro: en esta forma, y es, quando alguna muger está en el parto, y peligra, por tenerle malo, o no poder parir, si pide que le lleuen la santa Cinta, auisados los Mayordomos, conuocan a diez Cofrades, y van a la Seo, y tomando la Reliquia vn Sacerdote con Estola y habito de coro, cubierta con vn tafetán, la lleua a la muger que está en el peligro, acompañándole los diez Cofrades delante, a dos coros, con velas blancas encendidas en las manos, y llegados a la casa de la muger le ponen la arquilla encima, y dize la oración, y luego encima el Altar que para ello esté alli, no la dexa de vista el Sacerdote, acompañándole en vela dos de los Cofrades por horas, y en salir de peligro la muger, bueluen la Reliquia a la Sacristía, en la misma forma que la sacaron (ibid: 533-534).

La cinta se transportaba guardada en el interior de una pequeña caja, $\mathrm{y}$, como recogen los relatos de los milagros, no se sacaba nunca de ella:

auiendole puesto dicha Reliquia con su caxuela encima, poco después pario vn muchacho viuo [...]; apenas toco en ella la caxuela donde estaua diça Reliquia [...]; apenas puso la caxuela de la santa Reliquia sobre el vientre cuando pario [...]; al mismo tiempo que el testigo llegó, y puso la arquilla sobre el vientre pario [...]

El relicario que contenía la porción mayor de la cinta desapareció a fines de 1938 de los sótanos del Banco de España en Barcelona, donde fue depositado al estabilizarse el frente de guerra en Tortosa. El relicario con el pedazo más pequeño fue recuperado en Francia en 1939, siendo devuelto a Tortosa. 
Dos años después de la publicación de la obra de Martorel, en 1629, Felipe IV fue el primer monarca que solicitó la cinta. El motivo era el quinto parto de su segunda mujer, Mariana de Austria, del que nacería el Príncipe Baltasar Carlos. Quedaba así inaugurada una práctica que fue seguida en todos los nacimientos reales hasta Alfonso XIII. Cortés Echanove se hace eco de las sucesivas presencias en la Corte de la sagrada cinta, siempre siguiendo unas estrictas formalidades. Así, en los preparativos del nacimiento del infante Luis Antonio, hijo de Felipe $\mathrm{V}$ y de su segunda esposa Isabel de Farnesio (1727). O con motivo de los nacimientos de la infanta Carlota Joaquina, segunda hija de Carlos IV y M. ${ }^{a}$ Luisa de Borbón y Parma, en 1775, y del infante Carlos Domingo Eusebio en 1780. El expediente de este último embarazo dice:

Elegido por acuerdo capitular el Canónigo que había de ir a la Corte, congregábase el Cabildo al día siguiente en el Presbiterio con el Gobernador y el Corregidor de la ciudad, cinco Regidores de ésta, un Diputado del común y el Síndico Personero. Se cantaba una salve con la oración propia de la Santa Reliquia. Sin sacarla del relicario de plata que la contenía era éste encerrado en una cajita de madera, cubierta de terciopelo, con dos aldabillas y su llave. Sellada en ambas cerrajas con el sello catedralicio, recibía caja y llave el Canónigo elegido para conducirla con la debida decencia y veneración que a tan santa reliquia se debe a la Villa de Madrid, Corte de Su Mgd. (que Dios guarde), como lo manda por su Rl. Orden [...] Antes, aquel Canónigo juró en su Alma [...] que no dexaría ver la Sagrada reliquia a persona alguna sino en presencia del Rey ntro. Sor. y Serenos. Sres. Príncipes y Infantes y en la Capilla Real, ni la dejará de vista ni de su poder y que de dha, Sta. Reliquia no dará a nadie poco ni mucho y que la volvería cumplido el feliz alumbramiento de la Serma. Princesa de Asturias nuestra Sra. de la misma manera y forma (Cortés Echanove 1958: 153-154).

Cuando en 1784 Beltrán y Rius publica la traducción de su poema dedicado a la Sagrada Cinta (reimpresión de la edición de 1735), los viajes de la cinta a la corte con motivo de los alumbramientos reales estaban ya plenamente arraigados en la costumbre. El autor, además, presenta información actualizada, como demuestra la referencia al nacimiento de los gemelos de Carlos IV y M. ${ }^{a}$ Luisa de Borbón y Parma, que tuvo lugar justo un año antes de la publicación:

50. También apparecen los Milagros hechos por la intercesión de la Virgen de la Cinta: principalmente quando la Muger preñada pide el socorro de la Virgen, quando padece un parto molesto: luego acude esta piadosa Madre, y como Lucina Divina desata el parto difficoltoso, y el peso, que empuja al entumecido vientre ya maduro. $Y$ por esso haviendo tambien experimentado muchas vezes esto las Reynas de España, y las Princesas Reales, quando se hallan embarazadas con feto Augusto, mandan que se les lleven esta Sagrada Cinta, paraque con su patrocinio logren dar a luz una feliz Prole, y tengan favorables partos; $\left(^{*}\right)$ Y queriéndolo 
Dios, aunque ayan de parir dos Gemelos. Esto place á todos, esto quiere el Rey, y el Príncipe de Asturias, paraque puedan darnos muchos Hijos y Nietos, y no deseen [sic por dejen] sin Legitimo Sucesor á sus reynos, y puedan evitarse con esto muchas horribles Guerras en el Orbe, como tantas vezes una larga experiencia miserablemente nos lo ha manifestado.

(*) Esto se ha añadido por el feliz parto de la Princesa de dos Niños Gemelos, que con grande regosijo del Rey, i del Reyno fue en 5. de Setiembre Año de 1783 (Beltrán y Rius 1784: 31).

Fernando VII mantuvo la tradición, y en presencia de la Santa Cinta nació la futura Isabel II de su cuarto matrimonio con M. ${ }^{a}$ Cristina de Borbón. Y como no podía ser de otro modo, entre las numerosas reliquias que hacía reunir Isabel II en cada uno de sus partos siempre figuró la de Tortosa. Así, hasta los albores del siglo xx, durante casi trescientos años, la cinta fue solicitada por los monarcas españoles, los cuales desde Felipe V hasta Alfonso XIII estaban inscritos como Hermanos Mayores de la Cofradía de la Cinta.

Las continuas idas y venidas a la corte de la reliquia (Madrid, Aranjuez, El Pardo, Sevilla) se convirtieron en una excelente propaganda de sus virtudes milagrosas en lo que a partos se refiere. Los viajes necesariamente largos atravesaban la mitad del reino y no debían pasar desapercibidos. Desde Tortosa, la fama de la cinta se fue extendiendo por buena parte del país, de manera que a mediados del siglo xvil se solicitaron desde Mallorca "cintas tocadas a la original y libros que explicasen su historia" (Beguer Pinyol 1964: 111). Y a medida que su fama aumentaba y se extendía por el territorio, se incrementó también el número de sus intervenciones en todo tipo de enfermedades y desgracias. Beltrán y Rius (1784: 32) constata que todo ello hizo aumentar el número de ofrendas piadosas realizadas a la Virgen de la Cinta. Los milagros estaban narrados con el peculiar estilo de los exvotos pictóricos, "y por todas partes se ve la Muger libre de un infausto parto".

¿Cómo era la cinta? Martorel es el único historiador que la describe y la considera una "redecilla de hilo sutil ó de muy delgada seda, de color que tira a tostado. Otros autores afirman que es de seda (Arévalo y Lledó 1858: 84) ${ }^{8}$, pero los testimonios no se ponen de acuerdo. En 1853, cuando la cinta viajó a la corte para el parto de Isabel II, los reyes manifestaron su intención de mejorar el relicario. Para ello fue necesario sacar la

${ }^{8} \mathrm{El}$ autor afirma: "creemos que fundamentalmente no debe tenerse por un tejido de hilo, á tenor de la notivcia que dan de ella su antiguo inventario de la sacristía, que Pedro Sunyol, notario, tomó en 1354, pues bajo el día 27 de febrero dice así: Item la RECINTA de Madona santa Maria, la cual está en una caixeta de fust: es la RECINTA de sedan. 


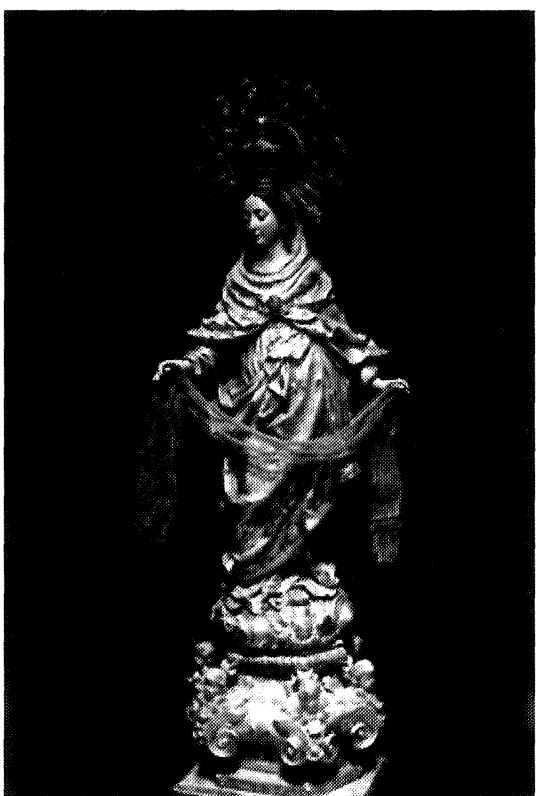

Figura 1.-Imagen de la Virgen de la Cinta. Siglo XVIII.

cinta, circunstancia que se aprovechó para verla de cerca: incluso entonces no se pudo determinar su materia, que unos testigos calificaron como seda, otros como pita, otros como lino y otros como algodón. En lo que sí coinciden todas las fuentes es en calificar al tejido como red sin nudos. Y en la forma, una red de ocho palmos de longitud, con dos palmos más en los extremos a modo de correa (Beguer Pinyol 1964: 108).

La representación más conocida de la Virgen de la Cinta, una imagen exenta de plata del siglo XVIII, sostiene entre sus manos el objeto que las fuentes describen: una banda larga y estrecha de punto de red (fig. 1). La necesidad de satisfacer la creciente demanda de la reliquia, de forma que no sólo beneficiara a los reyes, derivó en la confección de cintas similares a la auténtica que, tocadas a ésta, asumían sus virtudes. Esta santa industria estaba en manos de las monjas de Tortosa, que al parecer atendían pedidos de toda España (Pérez Sanjulián 1903: 3, 191).

El Museo Nacional de Antropología conserva dos medidas que, efectivamente, imitan al cinturón considerado original. La más antigua es una cinta de $180 \mathrm{~cm}$. de longitud y $9 \mathrm{~cm}$. de ancho; está realizada a punto de red con hilo plateado, dorado y rosado; cada extremo remata en un medallón con borde ondulado y borlas. En uno de los medallones, Virgen de la Cinta con el rostro pintado sobre placa de hueso, sosteniendo la reliquia entre sus manos; en el otro, monograma de María sobre media luna. El conjunto presenta una rica decoración a base de flores de talco, lentejuelas, estrellas bordadas y aplicaciones de hilo metálico. Procede de Guijo de Santa Bárbara (Badajoz) y se fecha en el siglo XVIII (n. ${ }^{\circ}$ inv. 10358).

La segunda mide $206 \mathrm{~cm}$. de longitud y $5.5 \mathrm{~cm}$. de ancho; también está realizada a punto de red, ahora con hilo de seda de colores azul, blanco y rosa, cuyos extremos se ensanchan ligeramente. En uno de ellos, Virgen de la Cinta con la cara y manos pintadas sobre papel, sosteniendo la reliquia; el manto está decorado con aplicaciones metálicas. Procede de Madrid y se fecha en el siglo XIX (n. ${ }^{\circ}$ inv. 8823). 
En la colección figura, además, una tercera medida, más moderna, de poliéster rosa. Mide $173 \mathrm{~cm}$. de longitud y $1.5 \mathrm{~cm}$. de ancho, y en ella figura la leyenda Medida del Sagrado Cingulo de Ntra. Sra. de la Cinta, venerada en la ciudad de Tortosa. Virgen Santisima, interceded por $m i$. Corresponde a la primera mitad del siglo $\mathrm{xx}$ (n. ${ }^{\circ}$ inv. 64152) (fig. 2).

Como último testimonio de la devoción a la medida de la Virgen de Tortosa es interesante recoger las advertencias que figuran en un Triduo - conjunto de ejercicios

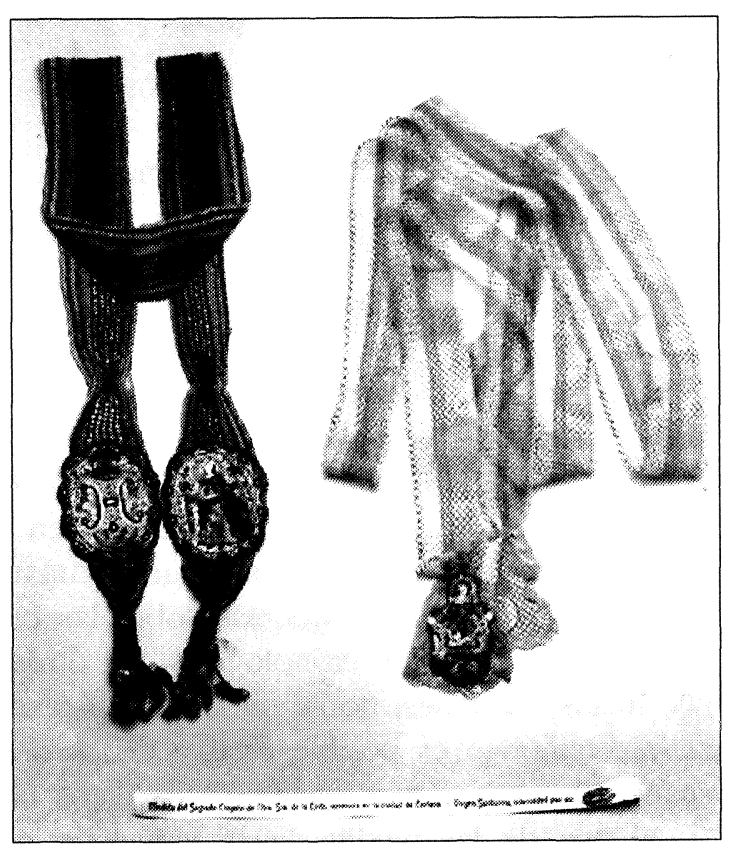

Figura 2.-Medidas del sagrado cíngulo de la Virgen de la Cinta. № inv. 10358, 8823 y 64152. devotos que se practican durante tres días-, fechado en 1862, del que se realizaron varias ediciones hasta, al menos, mediados del siglo xx (Valimaña 1948: 10). Mediante esta práctica, la mujer solicita a la Virgen que ésta le libre, o al menos le mitigue, los dolores del parto; que le libre de riesgos antes, durante y después del parto; amparo, consuelo y protección en el interesante estado en que me veo y, sobre todo, una feliz y pronta expedición en el acto del alumbramiento, y que la criatura salga a la luz sana, llegando al Bautismo sin desgracia:

Puesta de rodillas la mujer en la iglesia o en su misma casa, ante la imagen de la Virgen de la Cinta, rezará las oraciones que siguen, devota y fervorosamente: PRIMERO. Nueve Avemarías a la Virgen Santísima en memoria de los nueve meses que llevó a Jesús en sus purísimas entrañas, pidiéndole que la asista en su parto. SEGUNDO. Un Padrenuestro al Angel de la Guarda, otro a San Pedro Apóstol y otro a San Ramón Nonat, abogado de las parteras, con la misma intención.

TERCERO. Una Salve a la Santísima Virgen de la Cinta, para el mismo fin.

Lo hasta aquí referido no impedirá el que la mujer haga o rece a los Santos otras devociones, si las tiene y quiere rezarlas".

9 Entre las advertencias recomendadas para hacer este triduo me ha llamado la atención lo siguiente: “También el hablar poco y el vivir en retiro nos librará muchas 


\section{Medidas y cintas en Cataluña}

Son muchas las advocaciones marianas asentadas en el territorio de Cataluña que aparecen asociadas a medidas. En principio, esta circunstancia debe considerarse como indiscutible testimonio de la extensión de la práctica de medir imágenes sagradas. Es posible pensar, además, que la reliquia de la Virgen de la Cinta haya servido de modelo a las cintas de otras muchas advocaciones. No obstante, demostrar esta última hipótesis resulta muy complicado, ya que las referencias históricas a los santuarios que figuran en las medidas de la colección del Museo Nacional de Antropología no son homogéneas ni en calidad ni en cantidad.

En aquellos santuarios que gozan de una sólida tradición escrita, como Montserrat o Nuria, las noticias sobre las cintas aparecen con escasas o imprecisas referencias cronológicas. En otros, hasta bien entrado el siglo XIX, incluso después, no se publica la historia de la advocación, de manera que tampoco es posible establecer los orígenes de la práctica. Incluso cuando constan ciertas fechas, estos datos han de tomarse con reservas.

El uso de las medidas está vinculado con la especialización médica otorgada por la tradición a cada virgen. Por ello, en el caso de embarazos y partos, he considerado de interés establecer paralelismos entre las cintas de la colección y la información ofrecida por los gozos, comunes por lo demás a todos los santuarios catalanes. Este género de literatura popular, al presentar un didáctico resumen de las virtudes de la imagen, informa con bastante precisión de los casos médicos supuestamente solucionados en cada santuario, o al menos de los problemas que los fieles creían resueltos por la intercesión de la Madre de Dios.

1.-Partiendo de la base de que cualquier advocación mariana es intercesora general ante todo tipo de conflictos, en primer lugar se relacionan aquéllas que apuntan una cierta especialización en determinadas situaciones. Entre ellas destacan las vírgenes invocadas en embarazos y partos. Pero también las que resuelven problemas de la cabeza o de la vista.

\section{- Virgen de Nuria (Caralps, Gerona)}

Dice de ella el Jardín de María que es especialista "en alcanzar fruto de bendición a los casados y dando feliz parto a las mujeres preñadas, por lo cual es muy abogada y obra mucho". Así, en su extensa nómina

veces de los peligros que se hallan frecuentemente en el mundo: ver, oír, saber hablar y preguntar". 


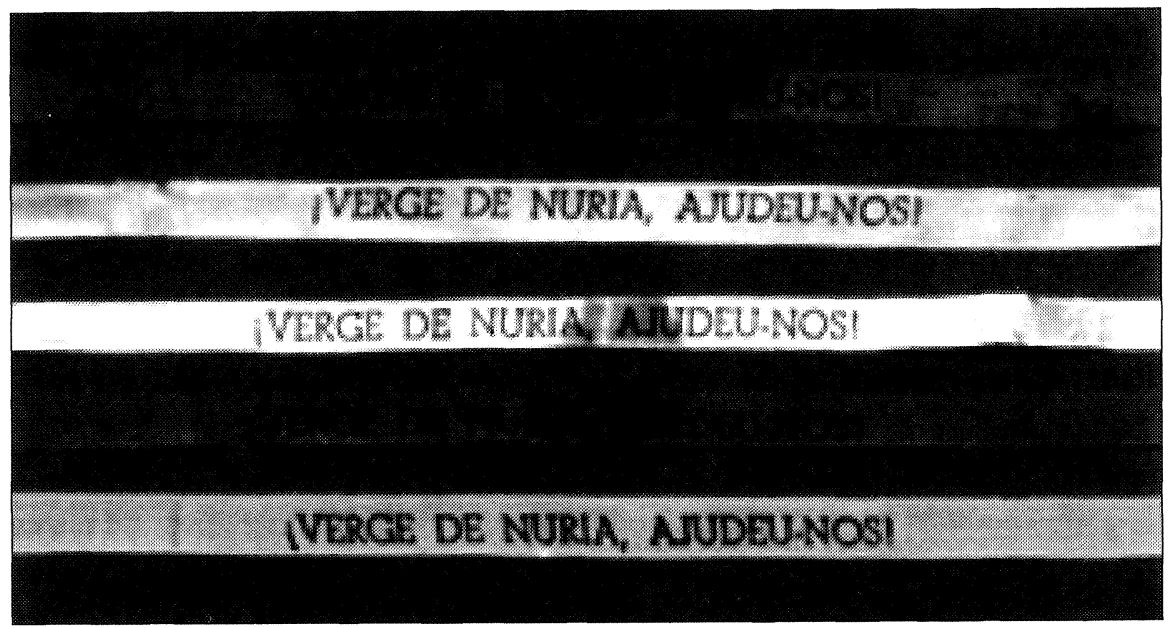

Figura 3.-Medidas de la Virgen de Nuria. N. ${ }^{\circ}$ inv. 64197-64201.

de milagros, los relacionados con la esterilidad de la mujer y el parto ocupan, al menos desde el siglo Xv, un lugar predominante. Contra la primera eran muy efectivas las visitas al santuario, donde se cumple el ritual en el que intervienen los atributos de la imagen (olla, campana y cruz): la mujer mete la cabeza en la olla, y el hombre toca la campana, besando ambos la cruz. Los gozos así lo indican:

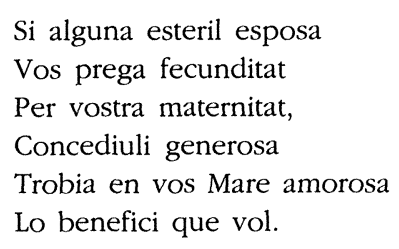

Como señala uno de los relatos, fechado en 1507 y titulado Deslliurá nostra Senyora á una dona que havia tres dias y tres nits que anava de part, al ceñir la cinta o mida a la parturienta, todo peligro desaparece (Marés 1882: 234-235).

Coincidiendo con la altura de la imagen, casi todas sus medidas tienen $70 \mathrm{~cm}$. de longitud, y en ellas figura la leyenda ;Verge de Nuria, Ajudeu-nos! (n. ${ }^{\circ}$ inv. 64197-64201) (fig. 3). Sólo una mide 120 cm., y presenta los atributos citados y la efigie de la virgen ( . $^{\circ}$ inv. 64202).

- Virgen de la Abellera (Santa María de Prades, Tarragona)

Su iconografía, que presenta al Niño mamando, es el primer indicio de su especialización. Las medidas corresponden a la altura de la imagen 
(n. ${ }^{\circ}$ inv. 64308, 64309). Los gozos del siglo xIX y comienzos del xx recogen alusiones tanto a enfermedades varias como al parto y a la lactancia; sin embargo, éstas últimas desaparecen en los más modernos:
Ha mostrat la experiencia, Que Coixos, Cegos, Ferits La dona que amb mal de pit Mancos, Trencats y Tullits A Vos acut fervorosa Curan, y demès dolencia: En Vos sempre generosa En lo part sempre qu'es hora, Troba un bàlsem escullit Socorren à la Partera. Que li dòna tot seguit Llet i salud duradera.

\title{
- Virgen del Remedio (Flix, Tarragona)
}

Sus medidas corresponden al brazo de la imagen. Se trata de cinco cintas de diversos colores unidas por una escarapela de tela (n. ${ }^{\circ}$ inv. 64184). Los gozos del siglo XIX y principios del XX dicen:
A la que con devoción
Mancos, tullidos y ciegos
á vos Virgen pura invoca
Paralíticos, llagados,
le dais a pedir de boca,
Se ven del todo curados
el fruto de bendición.
Con vuestros divinos ruegos.
En el parto su apretura
Para toda calentura
Asistís con gran consuelo.
Sois medicina del cielo.

- Virgen del Tallat (Vallbona de les Monges, Tarragona)

La medida propiamente dicha reproduce la estatura de la imagen (n. ${ }^{\circ}$ inv. 64148). En otra cinta, de mayor longitud, figura sin embargo la leyenda Record de la Mare de Déu del Tallat: este detalle la sitúa a medio camino entre las medidas y los objetos de recuerdo (n. ${ }^{\circ}$ inv. 64210).

Parece que su relación con el embarazo y el parto se remonta a finales del siglo XVI, cuando los marqueses de Camarasa tuvieron un hijo gracias a su intercesión. Este milagro se menciona en todos los gozos desde los primeros, publicados en 1762:

\author{
El Marquès de Camarasa \\ Obtinguè per Vos un fill, \\ Les prenyades en perill \\ Mai obliden vostra Casa, \\ Puix les han facilitar \\ El part 'en son temps i hora.
}

- Virgen del Milagro (Balaguer, Lérida)

Desde 1700 los gozos hacen referencia al poder curativo de sus estampas y vestidos, así como a su intervención en embarazos y partos. Su medida presenta las mismas dimensiones que otras del siglo XIX (VV. AA. 
1920: 55) ${ }^{10}$; la leyenda, sin embargo, hace referencia a su coronación, lo que la convierte, a la vez, en un objeto conmemorativo: ;Verge del Miracle, coronada: pregeu per nosaltres-Balaguer! (n. ${ }^{\circ}$ inv. 64307):

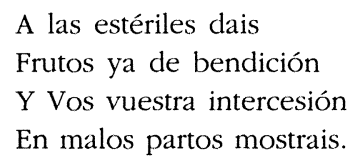

- Virgen de Juncadella (San Martín de Torroella, Barcelona)

Tal como indica la leyenda, la cinta reproduce la dimensión de la cabeza: Mida del cap de Ntra. Sra. de Juncadella. A pesar de que este tipo de medidas se relacionan generalmente con la curación de males de cabeza, aquí los gozos indican que también María es venerada como intercesora en los partos ( $n .^{\circ}$ inv. 64149):

$$
\begin{aligned}
& \text { Las donas que vos suplican } \\
& \text { En lo part son consoladas } \\
& \text { Las criaturas trencadas } \\
& \text { Per Vos curadas publican. }
\end{aligned}
$$

- Virgen de la Guía (Manresa, Barcelona)

En este caso sí parece clara la especialización de la Virgen en las enfermedades relacionadas con la cabeza. Según la leyenda que se remonta al siglo XVI, la imagen volvió la cabeza hacia el lugar donde se encontraba retirado san Ignacio de Loyola. La leyenda dice: Medida de la cabeza de Ntra. Sra. de la Guía de Manresa (n.' inv. 64142-64144, 6415364156).

\section{- Virgen de Butsénit (Butsénit, Lérida)}

Junto a la imagen se venera una pequeña piedra que los enfermos de la vista se pasan por los ojos. Con el mismo fin se usa la medida, en la que figura la leyenda Medida de Nuestra Señora de Butsenit (n.' inv. 64147):

$$
\begin{aligned}
& \text { En vuestras sagradas sienes } \\
& \text { Las contemplaba San Juan, } \\
& \text { Con doce estrellas que bienes }
\end{aligned}
$$

\footnotetext{
${ }^{10}$ Entre los objetos expuestos con motivo del LVII aniversario de la instalación de la Virgen del Milagro figuraron varias medidas: "Mida de $400 \times 15 \mathrm{~mm}$. De seda en variats colors, amb les paraules "medida de Ntra. Sra. Del Milagro". Mida o cinta de seda de $600 \times 15 \mathrm{~mm}$. Amb la inscripció gravada "Mida de l'alçaria de Nostra Senyora del Miracle de Balaguer" .
} 
2.- Un segundo grupo de medidas se relaciona con advocaciones marianas no especialistas. El devoto acude a ellas en todos los momentos conflictivos de su vida cotidiana: enfermedades, sequías, guerras, epidemias, etc. Su longitud no siempre coincide con la de la imagen. Salvo en el caso de Montserrat, corresponden a santuarios con un radio de influencia limitado al territorio más próximo:

- Virgen de Montserrat (Monistrol, Barcelona). Con la leyenda Medida de la cabeza de Santa María de Montserrat (n. ${ }^{\circ}$ inv. 64139, 64140, 64174), o bien Medida de la cintura de ntra. Sra. De Montserrat y de su bijo (n. ${ }^{\circ}$ inv. 64141).

- Virgen de la Providencia (Tortosa, Tarragona). Con la leyenda Medida de la milagrosa imagen de Nuestra Señora de la providencia-Ermita de Mig-Cami-Tortosa (n. ${ }^{\circ}$ inv. 64159, 64190).

- Virgen de Montornés (Puebla de Montornés, Tarragona). Con la leyenda Mida de la Mare de Déu de Pobla de Montornés (n. ${ }^{\circ}$ inv. 64161-64172).

- Virgen de la Fontcalda (Gandesa, Tarragona). Con la leyenda Medida de Ntra. Sra. de la Font-Calda (n. ${ }^{\circ}$ inv. 64207, 64208).

- Virgen de Bará (Bará, Tarragona). Con la leyenda Mida de Nostra Senyora de Bara (n. ${ }^{\circ}$ inv. 65274).

- Virgen del Milagro (Riner, Lérida). Con la leyenda Mida del cap de la Mare de Déu del Miracle (n. ${ }^{\circ}$ inv. 64206).

- Virgen de Ciervolés (Os de Balaguer, Lérida). Con la leyenda Mida de la Mare de Déu de Cervoles-Os (n. ${ }^{\circ}$ inv. 64209).

- Virgen de las Sogas (Bellvís, Lérida). Con la leyenda Medida de la imagen de Ntra. Sra. de las Sogues (n. ${ }^{\circ}$ inv. 64145, 64146).

3.-El último grupo incluye las cintas que deben considerarse objetos de recuerdo, y todas corresponden a advocaciones de carácter local. Su longitud no coincide con la altura de la imagen que representan:

- Virgen de Ciurana (Ciurana, Tarragona), también llamada Virgen del Agua. Con la leyenda Record de la mare de Déu de Ciurana ( $n .^{\circ}$ inv. 64310, 64311).

- Virgen de Barrulles (Capafons, Tarragona). Con la leyenda Verge de Barrulles-Capafonts ( $\mathrm{n}{ }^{\circ}$ inv. 64305).

- Virgen del Rosario (Vallmoll, Tarragona). Con la leyenda Ntra. Sra. del Roser. Vallmoll (n. ${ }^{\circ}$ inv. 64211, 64212, 64213). 
- Virgen de Loreto (Renau, Tarragona). Con la leyenda Ermita de Nostra Senyora de Lloret-Renau (n. ${ }^{\circ}$ inv. 64306) y otra con la leyenda Santuari de Ntra. Sra. del Loreto, sin indicación de localidad (n. ${ }^{\circ}$ inv. 65273).

\section{Estadales, cintas y medidas en Andalucía}

En la colección del Museo, las provincias de Jaén y Sevilla ofrecen una interesante variedad de cintas asociadas a la Virgen María. Aunque las fuentes no proporcionan descripciones precisas de estos objetos, entre ellos se distinguen con claridad al menos tres tipos.

El primero, tanto por el número de piezas como por el de advocaciones representadas, está constituido por los estadales. El estadal es, al menos desde hace medio siglo, una cinta de poliéster - antes pudo ser de seda o de algodón - con la medida de una imagen, pero tiene la particularidad de que sus extremos están cosidos, de manera que asemeja una especie de collar; además, lleva colgando una medalla de aluminio acompañada, en ocasiones, por un fleco de seda. Si bien su longitud no siempre coincide con la de la imagen representada, en todos los casos la cinta está cerrada y se acompaña de la citada medalla. Tanto su relación nominal con la medida de cera ya comentada, como el origen geográfico de las piezas parecen indicar su exclusiva pertenencia al ámbito devocional andaluz.

Los estadales de la colección corresponden a advocaciones que deben considerarse intercesoras generales y, por tanto, no especialistas. Sin embargo, la creencia más extendida los vincula de manera especial con el parto:

- Virgen de la Cabeza (Andújar, Jaén). Con las leyendas Recuerdo de Ntra. Sra. de la Cabeza de Sierra Morena, patrona de Andújar (n. ${ }^{\circ}$ inv. 64185), Viva Nuestra Señora la Virgen de la Cabeza de Sierra-Morena (n. ${ }^{\circ}$ inv. 64186) y Medida de Nuestra Señora la Virgen de la Cabeza, patrona de Andüjar (n. inv. 64187).

La invención de la Virgen de la Cabeza tuvo lugar en el primer cuarto del siglo XIII, y ya era famosa en buena parte de España a finales del XVI, cuando Cervantes describe su romería en Persiles y Segismunda. Desde entonces han sido muchas las páginas dedicadas a las tradiciones y prácticas que su culto ha generado. Adquiridos por los romeros en el santuario y luego tocados al manto de la virgen, medidas y estadales -así, diferenciados entre sí- aparecen citados en todas las fuentes. Por ejemplo, una crónica de finales del siglo XIX señala: "Baste decir, que, las medidas se venden por parejas, y los estadales por docenas" (Fe y Jiménez 1900: 219). 


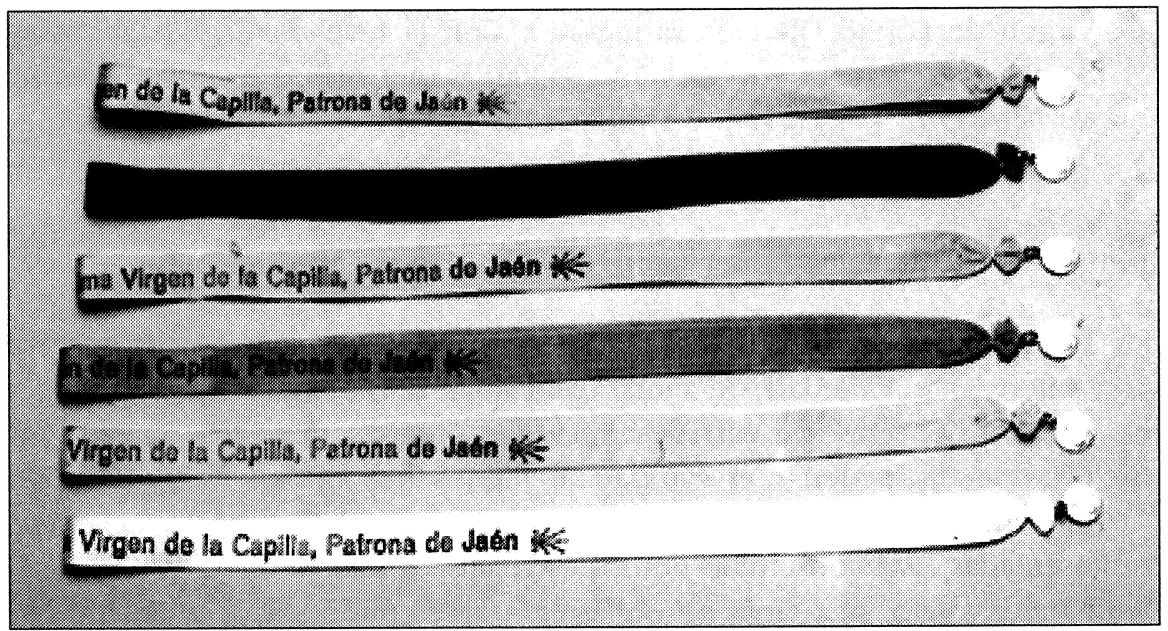

Figura 4.-Estadales de la Virgen de la Capilla. N. ${ }^{\circ}$ inv. 64190-64195.

La romería de Andújar cuenta, además, con otro documento que puede calificarse como excepcional. Se trata del cuadro de Bernardo Asturiano, fechado entre 1680 y 1690 , que presenta con singular detalle el ambiente del cerro de la Cabeza el día de la fiesta. Como señala Antonio Cea, en el camino que por la derecha sube a la ermita seis tenderetes ofrecen medidas y estadales azules, verdes, rojos y blancos (VV.AA. 1997: 83) ${ }^{11}$.

En la misma época, los más destacados miembros de la cofradía llevaban como distintivo unas bandas de diversos colores cruzadas sobre el pecho: roja el mayordomo y los diputados, y verde los comisarios; ya en el siglo xx se introdujeron bandas de colores azul y blanco. En mi opinión no resulta demasiado aventurado relacionar los estadales con dichas bandas, ya que ambos sólo se diferencian por su tamaño. Quedarían unidas así la tradición general de medir la imagen sagrada y la tradición local generada a partir de las cofradías.

Por otra parte, teniendo en cuenta la extensión geográfica y temporal alcanzada por el culto a la Virgen de la Cabeza, es posible pensar que este tipo de cinta haya servido de modelo a otras del entorno más próximo, cuyo culto se organizó con posterioridad:

- Virgen de la Capilla (Jaén). Con la leyenda Recuerdo de Ntra. Sra. la Santísima Virgen de la Capilla, patrona de Jaén (n. ${ }^{\circ}$ inv. 64190-64195) (fig. 4).

${ }^{11}$ Este cuadro es contemporáneo de la más exhaustiva historia de la advocación, obra de Manuel Salcedo Olid, Panegírico historial de Ntra. Sra. De la Cabeza de Sierra Morena, impreso en Madrid en 1677, editado en facsímil en 1994. 
- Virgen de Tíscar (Quesada, Jaén). Con la leyenda Recuerdo de Ntra. Sra. de Tíscar coronada, patrona de Quesada (n. ${ }^{\circ}$ inv. 64188).

- Virgen de Alharilla (Porcuna, Jaén). Con la leyenda ;Viva Ntra. Sra. de Albarilla, patrona de Porcuna! (n. ${ }^{\circ}$ inv. 64189).

- Virgen de Zocueca (Bailén, Jaén). Con la leyenda Viva Nuestra Señora de Zocueca, patrona de Bailén (n. inv. 64196).

El segundo tipo de cinta que en Andalucía aparece asociado con María es el denominado moñito. Se trata de una cinta de poliéster de diversos colores de $16 \mathrm{~cm}$. de largo por $3 \mathrm{~cm}$. de ancho, que lleva estampados la imagen de la virgen, su nombre y la localidad. Su nombre es un diminutivo de moño que, además del atado de pelo, significa lazo de cintas. En Andalucía es también usual el término moñita, que designa el lazo con que suelen adornarse la cabeza las mujeres. Según información de Antonio Limón, los moñitos son también adornos de las caballerías. En resumen, pues, estamos ante un adorno de origen profano que ha recalado en el terreno de la práctica religiosa.

Una crónica de la romería de Setefilla (Montoto 1975: 34) dice: "se da el nombre de moñitos a unos trozos de cinta de seda en los que va estampada la imagen de la Virgen. Son de muy varios colores. Se prenden con alfileres. Con ellos se engalanan los hombres las solapas de sus chaquetas y las mujeres se los prenden en sus blusas cuajándose el pecho de ellos. La Hermandad los vende por millares los días de romería".

Es posible que en el caso de esta última localidad sevillana los colores de los moñitos guarden relación con los colores de las banderas de cada uno de los gremios que componen la Hermandad Menor de Nuestra Señora María Santísima de Setefilla: el verde es el del Gremio de Agricultores o del Campo; el rojo del Gremio de Artesanos; el celeste del Gremio de Asociación Domiciliaria o Familiar; y la bandera nacional del Gremio de Excombatientes y Excautivos de la Cruzada Nacional.

- Moñitos de la Virgen de Gracia (Carmona, Sevilla), n. ${ }^{\circ}$ inv. 65275.

- Moñitos de la Virgen de Setefilla (Lora del Río, Sevilla), n. ${ }^{\circ}$ inv. 64176-64182 (fig. 5).

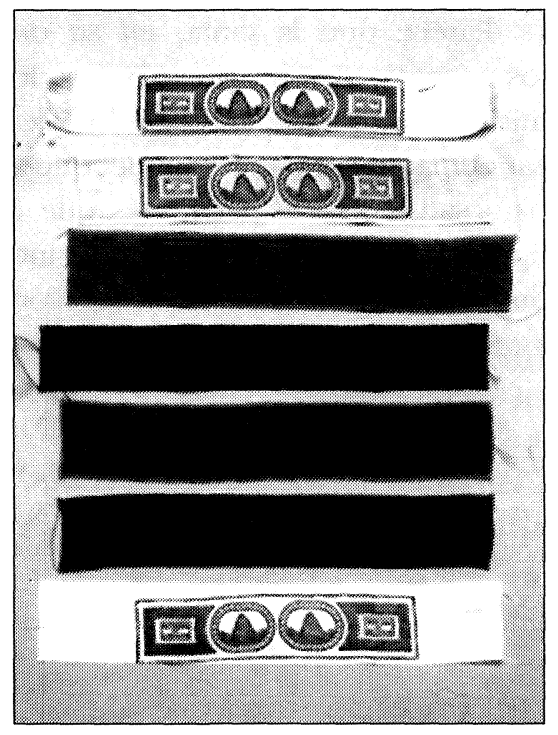

Figura 5.-Moñitos de la Virgen de Setefilla. N. ${ }^{\circ}$ inv. 64176-64182. 
Para terminar, las únicas cintas de la colección procedentes de Andalucía que repiten el modelo clásico de medida descrito más arriba corresponden precisamente a esta última advocación. Su dimensión reproduce la altura de la imagen y llevan la leyenda Medida de Nuestra Señora de Setefilla de Lora (n. ${ }^{\circ}$ inv. 64175 y 64183).

\section{Renacimiento $y$ decadencia de las medidas}

En este apartado se incluyen dos ejemplos que documentan la evolución sufrida por las medidas en el último medio siglo. En el primer caso, los cambios han supuesto la continuidad, incluso un cierto renacimiento, de la medida, mientras que en el segundo han derivado en una desaparición del culto a la advocación y, por tanto, de la propia cinta.

\section{- Virgen del Pilar (Zaragoza)}

Aunque sin lugar a dudas existió con anterioridad, la referencia más antigua a la medida de la Virgen del Pilar que he podido hallar es de 1759. Aparece en la crónica de la visita al Pilar realizada por Carlos III, acompañado por M. ${ }^{a}$ Amalia de Sajonia y los Infantes, en su primer viaje a España: “...el Capellán mayor ordenó que mientras estuviese el rey en Zarago$\mathrm{za}$, a todos los cortesanos se les obsequiase con una estampa, una medalla de indulgencia y una medida de seda" (Gutiérrez Lasanta 1975: 5, 187).

Parece que la cinta, en su origen, se consideraba como sustituta de los mantos que se prestaban a los enfermos - los denominados mantos misioneros, para diferenciarlos de los que nunca salían de la basílica-. La demanda era tan grande que se hizo necesario arbitrar esta solución para satisfacer las peticiones que llegaban desde todo el país y para todo tipo de casos médicos, partos incluidos. La medida se ponía y se pone durante la noche en contacto con la imagen.

Unos gozos del siglo XVIII dicen:

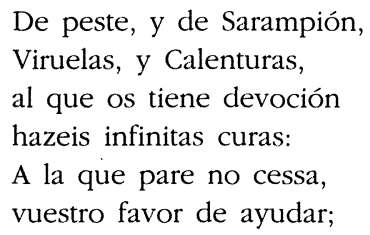

Pero el uso de la medida no se ha limitado a las situaciones relacionadas. Un artículo publicado en El Heraldo de Aragón el 12 de octubre de 1986 se hacía eco de las nuevas aplicaciones de la medida: 
Desde hace unos cuantos años, exactamente desde que comenzaron en España a producirse tantas muertes en carretera, los conductores de automóviles, y sobre todo de camiones, vieron en la "cinta de la medida" un medio de amparo y seguridad. Hoy son muchos los chóferes que la solicitan. Curiosamente, la suelen colocar en el retrovisor.

De este modo, ese pedazo de tela que era solamente, como el manto de los enfermos, "viático" para la eternidad, hoy es, además, talismán contra los percances en carretera.

La veracidad de esta información puede comprobarse con facilidad no sólo en Zaragoza, sino también, por ejemplo, en Madrid, donde estas medidas son relativamente fáciles de ver, colocadas efectivamente en el espejo retrovisor delantero tanto de taxis como de vehículos particulares.

Las cintas del Pilar pueden ser de varios colores, más suaves cuanto mayor es su antigüedad (blanco, azul, amarillo, rojo, verde, rosa y con los colores de la bandera de España) y en ellas un friso con motivos barrocos rodea a la virgen y a la filacteria con la leyenda Medida de Nuestra Señora del Pilar. Esta decoración ha permanecido invariable al menos durante el último siglo. Su longitud corresponde con exactitud a la altura de la virgen: $37.5 \mathrm{~cm}$. (n. ${ }^{\circ}$ inv. 64123-64127, 64157, 64158). En la actualidad se siguen vendiendo las medidas en el camarín de la Virgen a un precio de 100 pts. cada una. Junto a ellas figura una nota manuscrita que detalla sus propiedades:

Cintas de la medida de la Virgen (Suplen al manto de la Virgen). Para los enfermos: acompañados por Ntra. Sra. del Pilar, consuelo y fortaleza en el sufrimiento. Para los viajeros: compañía fiel y santificante en los desplazamientos. Siempre: vivir la presencia de la madre desde su pilar junto a nosotros.

\section{- Virgen de la Estrella (Barcelona).}

El Monasterio de Santa María de Jerusalén de Barcelona data de mediados del siglo xv. Recibió este nombre en recuerdo de la peregrinación que hizo su fundadora a Tierra Santa. Demolido en 1868, las sucesivas reedificaciones del mismo corrieron la misma suerte. Tras numerosas vicisitudes, la comunidad de religiosas franciscanas clarisas se estableció de nuevo en $1970^{12}$.

En el primitivo convento se veneraba la Virgen del Coro, también llamada Virgen de la Estrella por el distintivo que llevaba en la frente. Durante la peste que asoló Barcelona en 1615, la protección ejercida por la Virgen de la Estrella fue considerada providencial. Para consuelo de

${ }^{12}$ Una breve pero documentada historia del Convento de Jerusalén es la publicada por Antoni Paulí (1970). 
los devotos, las religiosas confeccionaron entonces unas cintas, que eran bendecidas y que estaban tocadas a la imagen. La Virgen de la Estrella también fue invocada con especial intensidad durante las distintas epidemias que conoció la ciudad a lo largo del siglo xIx y hasta la exclaustración. Según algunas fuentes, sus cintas se han continuado pidiendo para parturientas y enfermos hasta los años 40 del siglo xx.

Las dos medidas de la Virgen de la Estrella se fechan en el siglo XIX. En ambos casos se trata de una cinta de algodón blanco, de $1.5 \mathrm{~cm}$. de anchura. Una de ellas mide $61 \mathrm{~cm}$. y la leyenda, entre dos cruces de Jerusalén, dice: Medida de Nuestra Señora de la Estrella, Abogada contra la peste, que se venera en el Monasterio de Jerusalén de Barcelona (n. ${ }^{\circ}$ inv. 64150). La otra mide $69 \mathrm{~cm}$. y la leyenda se dispone entre dos estrellas, que marcan la verdadera altura de la efigie: Mida de nostra Senyora de la Estrella, Advocada contra la peste, que se venera en lo convent de jerusalem de Barcelona (n. ${ }^{\circ}$ inv. 64151).

Una estampa de la Virgen de la Estrella fechada en 1939 presenta la misma leyenda que la medida. En un intento de adaptación a los nuevos tiempos, tras la guerra civil se introducen algunas novedades en la estam$\mathrm{pa}$, de manera que el devoto ahora solicita de la virgen protección contra toda enfermedad del alma y del cuerpo. La leyenda entonces quedó como sigue: Ntra. Sra. de la Estrella, libradnos de toda peste del alma y del cuer$p o$. Pese a todo, una vez erradicada la enfermedad, parece que fue imposible mantener las connotaciones, incluso las espirituales, asociadas a ella. El culto público a la Virgen de la Estrella acabó desapareciendo.

\section{Medida de la Virgen de Bótoa (Badajoz)}

Hasta mediados del siglo XIX no vio la luz la primera historia de la Virgen de Bótoa, abogada de esta provincia extremeña e invocada en casos de sequía. La práctica de la medida, entendida como el testimonio de la protección que ejerce María sobre sus devotos, parece estar ya entonces arraigada en la tradición (Nogués Secall 1861: 61-62):

Entre tanto, la campana de la ermita llamaba á diferentes misas á los fieles, que iban presurosos á rendir culto á la Virgen. En el atrio se hallaban los encargados de la Hermandad expendiendo las medidas de aquella Señora, ó sea cintas de varios colores en que se hallaba impreso el nombre de Nuestra Señora de Bótoa. Los hombres rodean al sombrero este distintivo de su devoción, descendiendo flotantes los cabos sobre la espalda, las mujeres se las atan al cuello. Parecen los concurrentes á aquellos navegantes, que se embarcan para distintas regiones, que colocan en sus sombreros la cinta que indica el nombre de la embarcación en 
que van á atravesar el océano. Los devotos de la Virgen de Bótoa, dan á entender que bajo su protección se proponen también franquear el mar proceloso de la vida y llegar al puerto de la eternidad.

Coincidiendo con la altura de la imagen, la medida de Bótoa tiene una longitud de $100 \mathrm{~cm}$. y en ella figura la leyenda Medida de Nuestra Señora de Bótoa (n. ${ }^{\circ}$ inv. 41244-41247, 64173).

\section{Medidas en América. Virgen de la Caridad del Cobre (Cuba)}

Como otras devociones, el culto a la Virgen María se extendió con rapidez por territorio americano. Con el culto llegaron las distintas advocaciones marianas, arropadas por prácticas y tradiciones. Así ocurrió con el uso de las medidas.

La imagen de la Virgen de la Caridad y de los Remedios de la villa del Cobre, en Cuba, fue hallada en el mar a comienzos del siglo XVII. De su intercesión ante la enfermedad y los desastres naturales hablan en abundancia sus gozos, impresos en Barcelona en 1879. Como no podía ser de otro modo, esas coplas se refieren también a su intercesión en caso de esterilidad y en los partos:

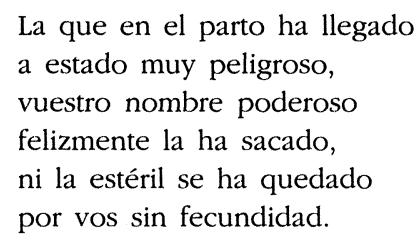

En la colección figuran tres medidas de esta advocación (n. ${ }^{\circ}$ inv. 6420364205), que corresponden a los primeros años del siglo xx. En ellas destaca el carácter descriptivo y didáctico de la leyenda: Medida de la milagrosa imagen de Nuestra Señora de la Caridad y de los Remedios de la Villa del Cobre, a 4 leguas de Santiago de Cuba. Está bendita y tocada a la sagrada imagen. Una de las cintas menciona, además, la declaración de la Virgen del Cobre como patrona de Cuba, realizada por Benedicto xv en 1916.

\section{CONCLUSIONES}

Mediante las medidas, la figura de María se vio reforzada en su dimensión más genuinamente protectora. A los ojos de los hombres, estas 
cintas sagradas han supuesto durante más de cinco siglos la oportunidad de poseer una representación tangible de las cualidades de la Madre de Dios. Y, por tanto, la posibilidad de resolver a través de ellas diferentes problemas, tanto individuales como colectivos.

Porque, siguiendo a Llompart (1984: 237): "parte de la importancia que hoy damos al retrato en tiempos antiguos la ha tenido la medida. Esta apreciación ha de tenerse en cuenta en el ámbito de la piedad popular, no sólo en la dirección de arriba abajo —-medidas de imágenes y objetos sacros-, sino también de abajo arriba —es, a saber, medidas y pesos en cera, tela y metal ofrecidos como exvotos". El estadal andaluz resume a la perfección la doble vía implícita en las medidas: siendo en origen un objeto de cera ofrecido por el hombre a la divinidad, una vez convertido en cinta y tocado a la imagen, transmite al devoto las cualidades y poderes de la imagen sagrada. En sentido inverso, las gracias concedidas por la intercesión divina, materializada en cintas, medidas y estadales, son devueltas por el hombre en forma de objetos cuyo peso (en el caso de las lámparas de plata) y longitud (en el caso de las telas para mantos) son siempre minuciosamente anotados en los libros de milagros y otros documentos. Para que conste.

Estas connotaciones, que han favorecido el uso ininterrumpido de las medidas - tan ligado en ocasiones al abuso-, también las han situado en ocasiones a medio camino entre la devoción y la superstición. Claro que buena parte de su indiscutible interés antropológico como objeto deriva precisamente de la sugerente mezcla de sentidos que encierran estos humildes fragmentos de cinta, ligados por lo demás a todas las clases sociales sin excepción.

Las medidas aparecen, además, asociadas a los momentos de auge del culto de los respectivos centros religiosos. En este contexto, a lo largo de los siglos xVII y xviII fueron entregadas como obsequio a los peregrinos reales en santuarios marianos tan emblemáticos como los de la Virgen de Guadalupe, la Virgen de Nieva o la Virgen de la Peña de Francia. Por ello en Covadonga, por ejemplo, el desarrollo de la práctica de medir la imagen se configura en un momento más tardío, el siglo XIX. Pero en todo momento y lugar, el conjunto de fieles en su totalidad acabó convirtiendo en tradicional la devoción hacia tales reliquias, asociándolas de manera especial con el embarazo y el parto.

En los últimos cien años, en contra de lo que podría suponerse, la vigencia de las cintas de la Virgen no parece haber disminuido. Más bien ocurre lo contrario. Por muy diversas razones (auge de las tradiciones locales, nostalgia del pasado, curiosidad ante determinadas creencias, etc.) -que, cómo no, siempre aparecen mezcladas de alguna manera con la 
fe en el poder taumatúrgico del pedazo de tela-, su tradición se muestra a comienzos del siglo XXI renovada y enriquecida con nuevos significados, lo que sin duda es el mejor seguro de continuidad en el tiempo.

\section{BIBLIOGRAFÍA CITADA}

AmAdes, J. 1950. Costumari catalá. Barcelona: Salvat Editores.

ARÉvalo y LlEDó, E. de. 1858. El Cíngulo de María. Leyenda tradicional y religiosa, escrita en verso. Tortosa: Imprenta de Vicente Miró.

Beguer Pinyol, M. 1964. La Santa Cinta de Tortosa. Breve bistoria documentada. Tortosa: Real Cofradía de Ntra. Sra. De la Cinta.

BELTRÁN Y RIUS, J. 1784. Traducción en prosa de lengua castellana del poema beroico latino del Sagrado Cíngulo de la Virgen María, que entregó en Prenda de su Amor à los bijos de la Fidelísima y Exemplar Ciudad de Tortosa... Tortosa: Imprenta de Josef Cid.

Christian, W.A. 1976. "De los santos a María: panorama de las devociones a santuarios españoles desde el principio de la Edad Media hasta nuestros días". Temas de Antropología Española: 49-105. Madrid: Akal.

- 1991. Religiosidad local en la España de Felipe II. Madrid: Nerea.

CORTÉs ECHANOVE, L. 1958. Nacimiento y crianza de personas reales en la Corte de España. 1566-1886. Madrid: Escuela de Historia Moderna.

FE y JiménEZ, L. 1903. Historia de Nuestra Señora de la Cabeza de Sierra Morena. Madrid: Establecimiento tipográfico de Ricardo Fe.

GUÍA PARA VISITAR LOS SANTUARIOS MARIANOS DE CATALUÑA. 1988. Barcelona: Encuentro.

Gutiérrez lasanta, F. 1975. Historia de la Virgen del Pilar. Tomo V. Las peregrinaciones. Zaragoza.

limón Delgado, A. y E. CASTEllote Herrero (eds.). 1991. El ciclo vital en España (Encuesta del Ateneo de Madrid, 1901-1902). Madrid: Museo Nacional del Pueblo Español.

LLOMPART, G. 1984. "Longitudo Christi Salvatoris". Entre la bistoria del arte y el folklore. Palma de Mallorca.

MALDONADO OCAMPO, L. 1952. "Sobre fecundidad y esterilidad". Hoja folklórica del Centro de Estudios Salmantinos, Sección de Costumbres Populares. Salamanca.

MARÉs, F. 1882. Historia y miracles de la sagrada imatge de Nostra Senyora de Nuria. Barcelona: Estampa de la llibrería religiosa.

MARTOREL Y DE LUNA, F. 1627. Historia de la antigua Hibera, con la milagrosa descensión de la Madre de Dios a su santo Templo, y la dadiua preciosa de la Santa Cinta,... Tortosa: En la imprenta de Jerónimo Gil.

Montoto, J. 1975. Tradiciones de Lora y Setefilla. Sevilla.

NOGUÉs SECALL, M. 1861. Reseña histórica acerca de la Virgen de Bótoa y su santuario, sito á dos leguas y media de Badajoz. Badajoz: Imprenta y librería de Jerónimo Orduña.

Paulí MelÉndez, A. 1970. El Reial Monestir de Santa Maria de Jerusalem de Barcelona. Barcelona: Tipografía Emporium.

PÉREz SANJulián, J. 1903. Historia de la Santísima Virgen María, del desarrollo de su culto $y$ de sus principales advocaciones en España y en América. Pamplona: Datafilm. 
REAU, L. 1983. Iconographie de l'art chrétien. Paris: Presses Universitaires de France. SATUÉ Oliván, E. 1991. Religiosidad popular y romerías en el Pirineo. Huesca: Instituto de Estudios Altoaragoneses.

VV. AA. 1997. La romería de la Virgen de la Cabeza en una pintura del siglo XVII. Córdoba: Cajasur.

VV. AA. 1920. Virgen del Milagro de Balaguer. Certamen público para solemnizar el aniversario LVII de su instalación. Lérida: Imprenta Mariana.

Valimaña, M. 1948. Triduo en honor de la Virgen Santísima de la Cinta para implorar, por su poderosa mediación, un feliz parto, compuesto por el rdo. Sr. D. Mariano Valimaña, Pbro. Beneficiado de la iglesia parroquial de Caspe, en 1862. Tortosa: Imprenta Blanch. 